\section{Reports Received}

\section{Canada}

- CEIC Report on CEIC/DSOS Consultation with Provincial Officials and Voluntary Sector Representatives on Immigrant Settlement and Integration. April 25-May 17, 1983.

U.S.

- The Congressional Record of May 18, 1983 which includes the (S-6907-6987) debates and proposed amendments to the U.S. Immigration Reform and Control Act dealing primarily with illegal immigration.

- Brief Answers to Frequently Asked Questions About Refugee Resettlement and Asylum, Refugee Policy Group, Washington.

- Testimony (June 1983) before the Senate and House Committees dealing with Immigration, Refugees and International Law by Dennis Gallagher and Julia Taft on behalf of the Refugee Policy Group re reauthorization of the Refugee Act of 1980 and program reforms.

- The Refugee Health Care System, A Background Paper on Policies, Programs and Concerns by the Refugee Policy Group, Washington.

- "Refugees and Migrants: Problems and Program Responses." The Ford foundation has written this 64-page report, which includes an overview of the global situation and description of the Ford Foundation's work around the world as part of its response to the world-wide refugee crisis.

U.N.

- "Refugee Aid and Development".

- Note on Procedures for the Determination of Refugee Status Under International Instruments".

- "Action Taken on Decisions by the Executive Committee". Outlines decisions made regarding problems related to asylum-seekers at sea, military attacks on refugee camps and settlements, assistance in Africa, the Americas, the Middle East and Southwest Asia.

- "Report of the United Nations board of Auditors to the Audit of the Accounts of Voluntary Funds Administered by UNHCR for the Year 1982". (Addendum) - "Report on UNHCR Assistance Activities in 1982-1983 and Proposed Voluntary Funds Programme and Budget for $1984 "$.

\title{
The Canadian Input
}

\author{
The 34th Executive Committee \\ UNHCR \\ Geneva, Oct. 14, 1983
}

Ambassador J. Alan Beesley, in the opening address to the UNHCR Executive Committee, genuflected approriately to support the High Commissioner's efforts with respect to the fundamental issue of protection and the need to address the root causes of refugee situations as outlined in the Aga Khan's report. Canada focussed on four issues, and it is not clear whether the ordering is significant: repatriation, local integration in countries of asylum, resettlement in third countries, and utilization of traditional settlement assistance to lessen both the likelihood and the impact of refugee situations.

Through the work of the subcommittee on protection, Canada assisted in developing a set of principles for the review of manifestly unfounded claims to refugee status, concurred in an agreement on a trial project for rescue at sea to which Canada makes a contribution, and urged continuing effort to develop a policy on preventing military attacks on refugee camps (on which there was no consensus). Canada also supported the promotion of existing legal instruments for the protection of refugees and urged the development of new, flexible and imaginative protection techniques.

The review of specific refugee situations around the world was supportive and diplomatic; it was neither analytic nor critical.

The address given by Canada's Permanent Mission in Geneva follows:

The Canadian delegation would like to add its voice to the numerous tributes to Director Moussali and Ambassador Kharma for their respective reports.

Given the difficulties and complexity of the issues discussed in the Committee, we categorically reject the suggestion of Ambassador Kharma that he failed in any way.

The subcommittee has achieved a number of positive results:

1. We have a set of principles for the review of manifestly unfounded claims to refugee status.
2. The subcommittee has agreement on a trial project for rescue at sea to supplement DISERO (which works well and to which, Canada makes a contribution).

3. On military attacks on refugee camps there was, it is true, no consensus but in our view, precision is more important than haste. As our Ambassador remarked during the general debate, even if it takes a year or two to gain consensus, it will be worth the effort.

On balance therefore we can take some satisfaction in the advancement of these issues which are vital to protection of refugees in various situations.

Mr. Chairman, the Note A/AC 96/623 on International Protection is a very useful document which highlights in a global perspective many of the problems member countries have been grappling with individually. We are encouraged by the paper, despite the gravity of problems it discusses in the field of international protection, and while there are ominous signs of deterioration in the standards of protection afforded refugees in some parts of the world, there is an essential belief expressed that the problems are not beyond our collective ability to solve. Despite some setbacks, the level of generosity displayed toward refugees particularly in the developing world, has been commendable.

It is evident in the paper submitted by the High Commissioner that there are two kinds of problems - that of structure of the system of international legal protections and equally important, of application of the principles toward people in need. Progress is needed in both areas if we are to meet today's challenges.

There is a thesis put forward in the paper that protection is being eroded because of the non availability of durable solutions. To some extent this is valid. But it must be borne in mind that in an historical perspective the current level of assistance to refugees and the number of refugees being resettled is ex- 
tremely high. While there have been decreases in some of these activities since the peak years of $1979 / 80$, the level of international sensitivity toward the needs of refugees remains strong, which gives ground for optimism and the belief in the fundamental goodwill of countries to see that refugees are protected.

With regard to the structure of the international legal system, some of the lacunae are mentioned in the paper, such as the lack of standards to be afforded asylum seekers until their claims have been determined. This also raises the classical problem that countries are required to allow refugees to remain but there is no requirement on states to admit refugees to their territories. A third contemporary problem is the growing tendency of refugees with de facto protection in one country to move spontaneously to another for the purposes, not of improving their protection, but of improving their standards of subsistence. In this regard the rights of the asylee and the obligations of country of first asylum and those of secondary or tertiary asylum, are not clear. Mr. Chairman, Canada supports the view that the legal principles of protection must be broadened in a creative way to better address these and other contemporary problems in the area of individual protection and the response to mass outflows. These gaps in the legal structure need to be filled in the interest of ensuring fair treatment and adequate protection to refugees.

Turning to the question of process, there are equally important problems. Not only is the issue that countries must live up to their obligations, but processes must be created to allow countries to apply the principles in a practical and fair manner. This latter issue is probably the most serious one facing us today.

The question of confusion between economic migrants and bona fide refugees is not simply a cynical rationalization used by countries to avoid having to honour the Convention obligation in respect of individuals or groups. The round table at Florence convened by the Institute of Humanitarian Law was particularly helpful in illuminating the issue of mass movements of which refugees form only a small part.

The Protection Subcommittee advanced the discussion on fair but expedient ways to cope with phenomenon through procedural devices to cope with abusive or manifestly unfounded claims. Canada is attempting to construct a model for dealing with claims on this basis to ensure fair treatment of asylum seekers, but at the same time protecting our asylum structure against abuse by other people seeking only a better standard of living.

While work goes ahead on these issues in Canada and elsewhere, Mr. Chairman, member governments are coming under increasing domestic pressure to use arbitrary means to curb what is often perceived to be penetration of their labour markets and social welfare systems through refugee processes. Unlike international instruments, domestic immigration laws can be changed in very short order. This creates the risk that the principle of nonrefoulment will be seriously eroded. In Canada's view, Mr. Chairman, it would be useful if standards to be observed by signatory countries in regard to the treatment of persons seeking admission could be codified.

In this same connection there has been considerable comment about the use of visas to control the influx of asylum seekers. Although the negative connotations are obvious, I would like to say that the consequences of the imposition of visas on citizens of countries that produce large numbers of claims are not necessarily all bad. It is normal practice in Canada, Mr. Chairman, to offset the effect of visa requirements by implementing special immigration measures to ensure refugees in need of resettlement will still have access to Canada through our embassies and consulates abroad. This allows us to target our help to those in most rieed while forestalling the spontaneous influx of those who are perhaps the best informed or the most resourceful, but not necessarily those in most need.

Finally Mr. Chairman, I would like to touch briefly on the question of compliance with the obligations laid on states by accession to the refugee Convention and Protocol. It has been stated in the document that the High Commissioner can only act through governments whose goodwill and cooperation are of paramount importance.

We feel, however, more use can be made of the stature of the High Commissioner's office to bring about redress to individual and general problems of noncompliance.

We should not underestimate the moral force of the HCR which was acknowledged in the Nobel Award in 1981.

It seems to us as well that where efforts of moral suasion by the UNHCR fail, interested countries should be prepared to join forces to add weight to the representations to individual governments. This might be done in tandem with other agencies of the United $\mathrm{Na}$ tions especially when political approaches become necessary.

Mr. Chairman, I would also like to pay tribute to the many non governmental organizations which both nationally and internationally have been vigilant and determined to combat breaches of asylum practices. The statement made by the representative of the International Council of Voluntary Agencies, during the general debate, serves to remind us of the importance of NGO's in the area at both the domestic and international levels.

In conclusion, Mr. Chairman, I would like to reiterate that in the absence of effective protection, discussion of any other forms of relief to refugee problems, is meaningless. We therefore support the suggestion that the legal principles need to be further developed and would be prepared to contribute to the process in a constructive way. 